\title{
Hubungan Sudut Pahat dan Kecepatan Potong Terhadap Pemakaian Mata Pahat Pada Pembuatan As-Arbor
}

\author{
Mualifi Usman $^{1^{*}}$, Ellysa Nursanti ${ }^{2}$, Dimas Indra Laksmana ${ }^{3}$ \\ ${ }^{1}$ CV Bumi Sampurno - Jombang \\ ${ }^{2,3}$ Teknik Industri, Program Pascasarjana, Institut Teknologi Nasional Malang \\ *Email: usman_mualifi@yahoo.com
}

\begin{abstract}
Abstrak
Sudut pemotongan pahat merupakan salah satu hal yang dapat mempengaruhi hasil pengerjaan pembuatan arbor. Kualitas permukaan potong tergantung pada kondisi pemotongan, dengan pemakaian standarisasi sudut pemotongan dan kecepatan potong kemungkinan akan didapat hasil kerataan yang sesuai. Pentingnya penentuan sudut pemotongan pahat dan kecepatan potong yang tepat dapat meminimalisir pemakaian mata pahat, dalam hal ini pada pembuatan arbor dapat dioptimumkan pemakaian mata pahatnya dengan menjaga geometri sudut pahat. Geometri pahat yang optimum memberikan proses pemotongan yang cepat dengan hasil yang halus serta keausan pahat yang minimum. Tujuan dari penelitian ini untuk mengetahui hubungan sudut pahat dan kecepatan potong terhadap pemakaian mata pahat pada proses pembuatan As-Arbor malalui pendekatan analisa regresi linier berganda. Pengaruh hubungan variabel sudut pahat dan kecepatan potong terhadap penggunaan mata pahat ditunjukkan dengan model rumusan regresi linier berganda yang ditunjukkan oleh $Y=641.568+31.481 X_{1}+11.571 X_{2}$. Nilai koefisien determinasi diperoleh 0.783 atau $78,3 \%$. Hasil penelitian menunjukkan bahwa semakin besar sudut pahat dan kecepatan potong semakin besar pula tingkat keausan mata pahatnya.
\end{abstract}

Kata kunci: Sudut Pahat, Kecepatan Potong, Pemakaian Mata Pahat, As-Arbor.

\section{Pendahuluan}

Arbor merupakan tempat memasang pisau frais pada setiap mesin frais, arbor juga dinamakan poros frais yaitu perlengkapan yang berguna sebagai tempat kedudukan pisau frais dan ditempatkan pada sumbu mesin. Arbor ada dua macam yaitu arbor panjang yang digunakan pada mesin frais horizontal dan arbor pendek digunakan pada mesin frais vertikal [1].

Sudut pemotongan pahat merupakan salah satu hal yang dapat mempengaruhi hasil pengerjaan pembuatan arbor. Kualitas permukaan potong tergantung pada kondisi pemotongan, dengan pemakaian standarisasi sudut pemotongan dan kecepatan potong kemungkinan akan didapat hasil kerataan yang sesuai [2].

Pentingnya penentuan sudut pemotongan pahat yang tepat dapat meminimalisir pemakaian mata pahat, dalam hal ini pada pembuatan arbor dapat dioptimumkan pemakaian mata pahatnya dengan menjaga geometri sudut pahat. Geometri pahat yang optimum memberikan proses pemotongan yang cepat dengan hasil yang halus serta keausan pahat yang minimum. Sudut pahat yang optimum diperoleh dengan pemilihan geometri pahat yang paling tepat untuk setiap karakteristik benda kerja. Dalam menentukan geometri sudut pahat yang efektif untuk setiap karakteristik material benda kerja, beberapa geometri sudut sudah ditentukan nilainya tetapi ada beberapa geometri yang nilainya masih memberikan range dan beberapa pilihan. Hal tersebut dimungkinkan karena material benda kerja juga memiliki range tingkat kekerasan, sehingga diperlukan variasi geometri sudut pahat. Sebagai contoh 
pada material aluminium, geometri sudut pahat yang efektif digunakan pada pahat HSS adalah sudut bebas orthogonal $(\alpha o) 12^{\circ}$, sudut potong bantu ( $\left.\kappa^{\prime} r\right) 60^{\circ}$, sudut geram orthogonal $\left(\gamma_{0}\right) 14^{\circ}-30^{\circ}$, sudut potong utama $(\mathrm{\kappa r}) 45^{\circ}, 75^{\circ}, 90^{\circ}$, sudut penampang orthogonal $48^{\circ}-64^{\circ}$. Geometri tersebut adalah geometri yang dapat meminimumkan temperatur proses pemotongan. Temperatur bidang aktif pahat yang dihasilkan setaraf dengan besarnya dimensi keausan yang dianggap sebagai batas atau tanda saat berakhirnya umur pahat [3].

Kecepatan potong (Cutting Speed/Cs) adalah kemampuan alat potong menyayat bahan dengan aman menghasilkan tatal dalam satuan panjang/waktu (mm/menit atau feet/menit) [4]. Menurut pendekatan empirik Kienzle, dalam jurnal criterion to evaluate diffusive wear in $3 D$ simulations when turning AISI 1045 stell, [4]. Menyatakan bahwa interaksi antara benda kerja dengan pahat sekaligus proses terjadinya geram pada parameter permesinan kecepatan potong (cutting speed) diperoleh kecepatan optimum 80, $100,120,150,180 \mathrm{~mm} / \mathrm{min}$.

Berdasarkan uraian kajian toritis diatas dapat diketahui bahwa permasalahan dalam pembuatan arbor yang baik yaitu berhubungan dengan geometri sudut pahat dan kecepatan potong. Dengan demikian tujuan penelitian ini adalah untuk mengetahui hubungan sudut pahat dan kecepatan potong terhadap pemakaian mata pahat pada pembuatan proses as-arbor. Melalui pendekatan analisa regresi linier berganda.

\section{Metodologi Penelitian}

Penelitian ini menggunakan metode desain ekperimen melalui pendekatan regresi linier berganda. Variabel kondisi pemotongan seperti sudut pahat $K_{r}$, kecepatan potong $\mathrm{V}$, untuk mendapatkan jumlah pahat yang terbuang pada proses pembuatan as-arbor, ditetapkan bervariasi. Metode eksperimen dirancang berdasarkan tingkatan pengujian dilakukan pada berbagai kondisi sudut pahat dan kecepatan potong. Pengujian bubut dilakukan lebih dahulu, untuk material benda kerja yang dimesin akan disesuaikan dengan kemampuan putaran mesin. Sebelum pemotongan, lebih dahulu dikondisikan sudut mata pahat dan kecepatan potongnya untuk dicatat, kemudian dilakukan pemotongan dengan kedalaman potong dan pemakanan sesuai dengan kondisi pemotongan, lalu dilakukan penimbangan sisa mata pahat terpakai. Adapun perencanaan pengerjaan sebagai berikut :

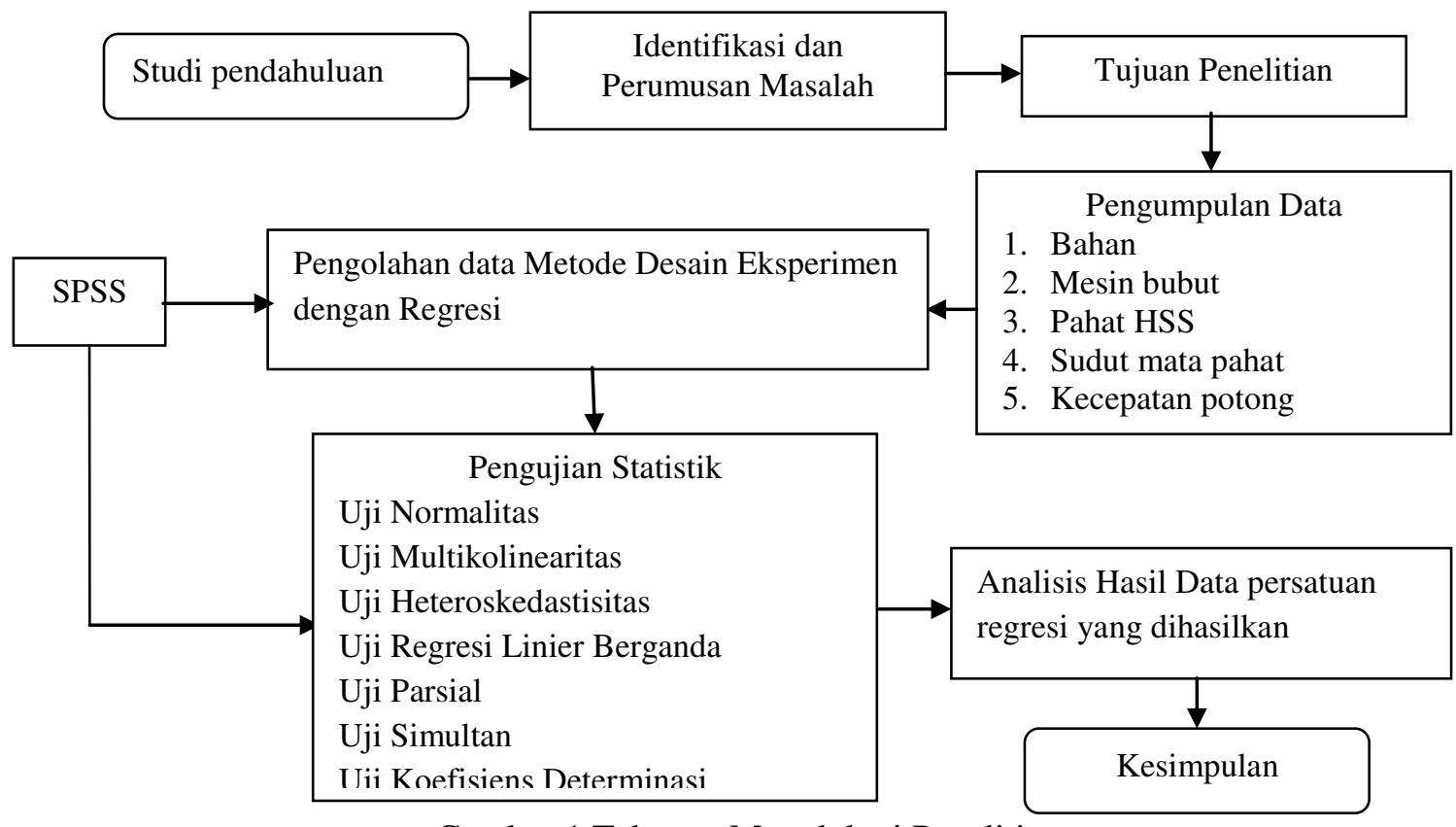

Gambar 1 Tahapan Metodologi Penelitian 


\section{Hasil dan Pembahasan}

Eksperimen dilakukan dibengkel di CV. Bumi Sampurno dengan merencanakan sudut pahat dan kecepatan potong terhadap pembuangan mata pahat. Diketahui bahwa pengujian eksperimen dilakukan sebanyak 12 specimen dengan nilai sudut pahat masing-masing $30^{\circ}, 45^{\circ}, 60^{\circ}, 90^{\circ}$ dengan nilai kecepatan potong dan mata pahat yang berbeda pada tiap nilai sudut pahat. Kondisi awal indikator hasil pembuangan mata pahat lihat Tabel 1 , sebagai berikut:

Tabel 1. Data Yang Digunakan Dalam Ekperimen

\begin{tabular}{cccccc}
\hline $\mathbf{3 0}^{\circ}$ & 50 & 1764 & $60^{\circ}$ & 50 & 3534 \\
& 120 & 2767 & & 120 & 3532 \\
& 150 & 2750 & & 150 & 4537 \\
$\mathbf{4 5}^{\circ}$ & 50 & 3413 & $90^{\circ}$ & 50 & 3536 \\
& 120 & 3414 & & 120 & 4546 \\
& 150 & 4417 & & 150 & 5549 \\
\hline
\end{tabular}

\section{Pengujian asumsi klasik}

Uji asumsi klasik regresi linier berganda adalah persyaratan statistik yang harus dipenuhi pada analisis regresi linear berganda yang berbasis Ordinary Least Square (OLS). Dalam penelitian ini terdapat tiga uji asumsi yang harus dilakukan yaitu uji normalitas, uji multikolinieritas, dan uji heteroskedastisitas.

Uji normalitas adalah uji untuk mengukur apakah data yang didapatkan memiliki distribusi normal sehingga dapat dipakai dalam statistik parametrik (statistik inferensial). Uji statistik normalitas yang digunakan diantaranya menggunakan metode grafik dan Kolmogorov Smirnov. Berdasarkan Tabel 2 Kolmogorov-smirnov diperoleh nilai $\mathrm{Z}$ sebesar 0.593 dan nilai ini berada $>0.05$ menunjukan bahwa model regresi berdistribusi normal.

Tabel 2. Kolmogorov-Smirnov Test

\begin{tabular}{llr}
$\mathbf{N}$ & & 12 \\
\hline Normal Parameters $^{\mathbf{a}}$ & Mean & .0000000 \\
& Std. Deviation & $4.67973071 \mathrm{E} 2$ \\
Most Extreme & Absolute & .171 \\
Differences & Positive & .171 \\
& Negative & -.135 \\
Kolmogorov-Smirnov Z & & .593 \\
Asymp. Sig. (2-tailed) & & .873 \\
\hline
\end{tabular}

Uji multikolinearitas bertujuan untuk mengetahui adanya hubungan antara beberapa atau semua variabel yang ada dalam model regresi. Jika dalam model terdapat multikolinearitas maka model tersebut memiliki kesalahan standar yang besar sehingga koefisien tidak dapat ditaksir dengan ketepatan yang tinggi. Berdasarkan dari Tabel 3 uji multikolinieritas nilai keseluruhan variabel memiliki nilai toleransi diatas 0.1 dan nilai VIF lebih kecil dari 10. Hal ini menunjukkan bahwa tidak terjadi multikolinieritas.Hasil pengujian multikolinieritas pada Tabel 3 sebagai berikut : 
Tabel 3. Hasil Uji Multikolinieritas

\begin{tabular}{|c|c|c|c|c|c|}
\hline & & Beta & & Tolerance & VIF \\
\hline \multirow[t]{3}{*}{1} & (Constant) & & & & \\
\hline & Sudut_Pahat_X1 & & .727 & 1.000 & 1.000 \\
\hline & Kecepatan_Potong_X2 & & .504 & 1.000 & 1.000 \\
\hline
\end{tabular}

Uji heteroskedastisitas bertujuan untuk menguji apakah dalam model regresi terjadi ketidaksamaan variance residual dari satu pengamatan ke pengamatan yang lain. Jika variance dari residual satu pengamatan ke pengamatan lain tetap, maka disebut homoskedastisitas dan jika berbeda disebut heteroskedatisitas. Berdasarkan Tabel 4 uji heteroskedastisitas diketahui nilai sig pada semua variabel > dari 0.05 hasil ini membuktikan bahwa model regresi tidak terjadi heteroskedastisitas.

Tabel 4. Hasil Uji Heteroskedastisitas

\begin{tabular}{lllll}
\multicolumn{5}{c}{ Beta } \\
\hline 1 & & 2.612 & .028 \\
& (Constant) & -.067 & -.213 & .836 \\
& Sudut_Pahat_X1 & -.306 & -.968 & .358 \\
\hline
\end{tabular}

Uji Regresi Linier Berganda bertujuan utuk mengetahui ketergantungan variabel dependen (terikat) dengan satu atau lebih variabel independen (bebas) dengan tujuan untuk mengestimasi dan atau mempediksi rata-rata populasi atau nilai rata-rata variabel dependen berdasarkan nilai variabel independen. Pada Tabel 5 uji regresi linier berganda diperoleh rumusan regresi linier berganda $Y=641.568+31.481 X_{1}+11.571 X_{2}$.

Tabel 5. Hasil Uji Regresi Linier Berganda

\begin{tabular}{llrrr}
\hline & & & \\
& & \multicolumn{1}{c}{ B } & Std. Error & Beta \\
\hline 1 & (Constant) & 641.568 & 557.009 & \\
& Sudut_Pahat_X1 & 31.481 & 6.732 & .727 \\
& Kecepatan_Potong_X2 & 11.571 & 3.564 & .504 \\
\hline
\end{tabular}

Uji Parsial adalah Pengujian T hitung digunakan untuk mengetahui kualitas keberartian regresi antara tiap-tiap variabel bebas $(\mathrm{X})$ terdapat pengaruh atau tidak terhadap variabel terikat (Y). Berdasarkan Tabel 6 hasil uji parsial (t-test) diperoleh penjelasan sebagai berikut :

1. Variabel $X_{1}$ Sudut Pahat nilai t hitung sebesar $4.676>$ dari $t_{\text {tabel } 0.05}=2.262$.

2. Variabel $X_{2}$ Kecepatan Potong nilai t hitung sebesar 3.246> dari $t_{\text {tabel } 0.05}=2.262$.

3. Disimpulkan bahwa variabel sudut pahat $\left(X_{1}\right)$ dan kecepatan potong $\left(X_{2}\right)$ secara parsial hipotesis diterima dan secara parsial berhubungan dengan mata pahat.

Tabel 6. Uji Parsial 
Uji Simultan adalah Uji F digunakan untuk mengetahui apakah variabel-variabel independen secara simultan berpengaruh signifikan terhadap variabel dependen. Derajat kepercayaan yang digunakan adalah $5 \%$. Apabila nilai $\mathrm{F}$ hasil perhitungan lebih besar dari nilai $\mathrm{F}$ tabel maka hipotesis alternatif yang menyatakan bahwa semua variabel independen secara stimultan berpengaruh signifikan tehadap variabel dependen. Dari Tabel 7 Uji silmutan (f-test) diketahui nilai sig perhitungan lebih kecil dari 0.05 dan nilai $F$ hitung $16.203>3.86$. jadi disimpulkan bahwa secara keseluruhan variabel sudut pahat $X_{1}$ dan kecepatan potong $X_{2}$ secara simultan pengaruh signifikan dengan keausan mata pahat $(\mathrm{Y})$.

Tabel 7. Analisis ANOVA : Hubungan Antara Sudut Pahat dan Kecepatan Potong

\begin{tabular}{llrrrrr}
\hline 1 & Regression & 8673874.173 & 2 & 4336937.087 & 16.203 & $.001^{\mathrm{a}}$ \\
& Residual & 2408986.744 & 9 & 267665.194 & & \\
& Total & $1.108 \mathrm{E} 7$ & 11 & & & \\
\hline
\end{tabular}

Uji Koefisien Determinasi Analis koefesien determinasi dalam program regresi linier berganda digunakan untuk mengetahui presentase hubungan pengaruh variabel independen $\left(X_{1}, X_{2}\right)$ secara serentak terhadap variabel dependen (Y).

Tabel 8. Analisis R² : Hubungan Antara Sudut Pahat dan Kecepatan Potong

\begin{tabular}{llll}
\hline $\mathbf{1}$ & $.885^{\mathrm{a}}$ & .783 & .734 \\
\hline
\end{tabular}

Sedangkan Koefisien determinasi dapat dilihat pada Tabel 8 diperoleh nilai angka R square 0.783 atau $78,3 \%$, hal ini berarti prosentase pengaruh variabel sudut pahat dan kecepatan potong terhadap kausan mata pahat sebesar $78,3 \%$, atau variasi variabel sudut pahat dan kecepatan potong mampu menjelaskan sebesar 78,3\% keausan mata pahat. Untuk sisanya bisa dipengarhi variabel yang lain, yang tidak diikutkan dalam penelitian ini misalnya pahat HSS, material benda kerja.

\section{Kesimpulan}

Pada pembuatan as-arbor dibutuhkan beberapa sudut pahat yang optimal dan kecepatan potong yang optimal pula, as-arbor kenapa sering kali diganti karena pada proses pengerjaan pengefresan as-arbor terhubung dengan poros utama atau gerakan putaran mesin frais, fungsi as-arbor adalah sebagai dudukan pisau frais yang mana pada penggunaanya sebagai penyangga end mill/pisau frais. Pengaruh hubungan variabel sudut pahat dan kecepatan potong terhadap penggunaan mata pahat ditunjukkan dengan model rumusan regresi linier berganda $Y=641.568+31.481 X_{1}+11.571 X_{2}$. Penelitian ini memiliki nilai koefisien determinasi diperoleh 0.783 atau $78,3 \%$. Hal ini menunjukkan prosentase pengaruh variabel sudut pahat dan kecepatan potong terhadap kausan mata pahat mampu dijelaskan sebesar 78,3\% . semakin besar sudut pahat dan kecepatan potong, semakin besar pula tingkat keausan mata pahat. 


\section{Daftar Referensi}

[1] Widarto. Teknik Pemesinan Jilid 1.Jakarta :Direktorat Pembinaan Sekolah Menengah Kejuruan, Direktorat Jendral Manajemen Pendidikan dan Menengah, Departemen Pendidikan Nasional. 2008.

[2] Susarno, Ardiyan. Studi Pengaruh Sudut Potong Pahat HSS Pada Proses Bubut Dengan Tipe Pemotongan Orthogonal Terhadap Kekasaran Permukaan, http://eprints.ums.ac.id/21730/, 2012.

[3] Rochim, Taufiq, Teoridan Teknologi Proses Pemesinan, Laboratorium Teknik Produksi, Jurusan Teknik Mesin, FTI, Bandung, ITB, 1993.

[4] Paradiwati, Pengaruh Kecepatan Dan Sudut Potong Terhadap Kekasaran Benda Kerja Pada Mesin Bubut, Jurnal Ilmiah Teknik Mesin, Vol 3, No 1, 53-67, 2015.

[5] Attanasio, A, dkk. Criterion to evaluate diffusive wear in 3D simulations when turning AISI 1045 steel, International Jurnal Master Form, no. 1, pp. 495-498, 2008. 